\title{
Strength and Stiffness Behavior of Earthquake Resistant Pedestrian LVL Timber Bridge
}

\author{
Bernardinus Herbudiman, Delima, and Yosafat Aji Pranata
}

\begin{abstract}
A bridge is a structure which is used to connect two areas separate by obstacles. The environmental damage caused a number of reductions in the production of timber, and by that, the LVL timber which is a high quality processed or engineered timber is chosen. This research determined the design of the timber bridge structure for pedestrian with simple beam type and earthquake resistant. The load in this bridge is referring to the SNI 1725:2016 and SNI 2833:2008, the design of the girder and the connection is referring to SNI 7973:2013, and the deflection is referring to the LFRD for Highway Bridge Superstructures. The timber bridge is designed to have a span of 10 metres long and 3 metres wide. The modeling and designing of the wooden bridge are using an application called SAP2000 based on finite element analysis. Result obtained from this research indicated that the longitudinal dimension of the girder is $360 \mathrm{~mm} \times 630 \mathrm{~mm}$ and the cross sectional dimension is $180 \mathrm{~mm} \times 270 \mathrm{~mm}$. The number of bolts and lock screws needed on the connection among the longitudinal girders are 40 pieces, between the longitudinal girders and the cross sectional girders is three pieces, and between the railing and the slab are two pieces. Based on the stiffness review, the results showed that the bridge deflection that occurred was lower than the permit deflection.
\end{abstract}

Keywords: Timber bridge, strength, stiffness, pedestrian bridge, LVL.

\section{Introduction}

Government Regulation of the Republic of Indonesia Number 34 Year 2006 Article 86 Paragraph (3) explains that the definition of a bridge is a road that is located above water level and/or above ground level. Therefore, a bridge is a structure that functions to connect two areas with obstacles such as rivers or valleys. A wooden bridge is a type of bridge that uses wood materials with a fairly simple construction method when compared to other types of bridges. One type of bridge based on its use is a pedestrian bridge. Several pedestrian bridges or light vehicles are useful for connecting two areas that are separated by rivers, especially in tourism areas such as waterfall attractions, parks near rivers, and there tourist attractions (lakes).

LVL (Laminated Veneer Lumber) wood is processed wood consisting of a thin layer or wood veneers which are glued together on both sides and then pressurized. Gluing is carried out following the long direction of the wood. Therefore, the cross-sectional size of LVL wood can be adjusted so that it can be used as a building block for structural components. LVL wood is a potential material that can be used for the manufacture of wooden bridge structures.

Research related to the use of LVL Sengon (Paraserianthes falcataria) wood in building structures and bridges has been carried out, including for gable frame structures (Awaludin and Astuti 2016), for truss-type bridge structures for vehicles (Herbudiman et al. 2017), and as a component of shear wall structures in buildings (Awaludin et al. 2018). Research on the use of other wood such as coconut wood for a truss-type bridge structure has also been carried out (Pranata et al. 2016), namely the truss-type bridge structure uses coconut wood.

This research determined the design of the timber bridge structure for pedestrian with simple beam type and earthquake resistant. The load in this bridge is referring to the SNI 1725:2016 (BSN 2016) and SNI 2833:2008 (BSN 2008), the design of the girder and the connection is referring to SNI 7973:2013 (BSN 2013), and the deflection is referring to the LFRD for Highway Bridge Superstructures. The timber bridge is designed to have a span of ten meters long and three meters wide. The modeling and designing of the wooden bridge are using an software called SAP2000 based on finite element analysis.

\section{Basic Theory}

Wood is a material produced by nature so it is easier to obtain. Therefore, in ancient times wood material was used as an alternative choice for making infrastructure such as dwellings and bridges. However, along with increasingly advanced technology, wood materials are rarely used.

The simple beam bridge is the simplest bridge design among modern bridges today. Consists of horizontal road beams and is supported by beams that support the horizontal road. These stowed bearings withstand or resist the downward weight of the road body and the loads above it. This bridge model is more suitable for short distances such as connecting roads that are separated by rivers. In addition, if the road is getting longer, more beams must be systematically made to withstand the load so that it is not easily collapsed due to stress and compression. Simple beam bridges are usually intended for railways or connections between villages that are separated by rivers. 
Wood is a natural resource which is currently used mostly in the plywood industry, such as furniture. It can be said that there is very little direct use of the bridge as the main construction. At least use wood as formwork for bridges.

A pedestrian bridge is a bridge whose bridge users are limited to pedestrians and light vehicles such as bicycles, motorbikes and light motorized vehicles with a maximum of three wheels can pass for emergencies. The dead load, live load, wind, and earthquake are used in pedestrian bridge modeling. Dead loads are all loads that come from the bridge's own weight, including all additional elements which are considered to be a permanent unit. Live loads are all loads that come from pedestrians, and are possible for light vehicles. Wind load is a load due to pressure moving horizontally. Meanwhile, earthquake loads are loads that work on a structure as a result of ground movement caused by an earthquake. Values for response spectrum curves can be obtained from the Research and Development Center of Settlement's website, these values vary depending on the area under review.

Based on SNI 1725: 2016 (BSN 2016) concerning Loading Standards for Bridges, the distribution of live loads for pedestrian loads and lane loads is pedestrian load, namely $5 \mathrm{KPa}$, wind load, namely the determined wind pressure is assumed to be caused by a planned wind with a basic speed $\left(V_{B}\right)$ of 90 to $126 \mathrm{~km} /$ hour. For bridges or bridge sections with an elevation higher than $10000 \mathrm{~mm}$ above the ground or water level, the design wind speed $\left(V_{D z}\right)$ and the design wind pressure $\left(\mathrm{PD}_{\mathrm{D}}\right)$ is calculated by the following equation:

$$
\begin{aligned}
& V_{D Z}=2,5 V_{0}\left(\frac{V_{0}}{V_{B}}\right) \ln \left(\frac{Z}{Z_{0}}\right) \\
& P_{D}=P_{B}\left(\frac{V_{D Z}}{V_{B}}\right)^{2}
\end{aligned}
$$

with:

$V_{D Z}=$ design wind speed, $Z$ [km/hour],

$V_{10}=$ wind speed at elevation $10000 \mathrm{~mm}$ [km/hour],

$V_{B}=$ design wind speed which are 90 to $126 \mathrm{~km} /$ hour at elevation $1000 \mathrm{~mm}$,

$Z \quad$ = elevation of structurre where wind load calculated $(Z>10000 \mathrm{~mm})$,

$V_{0}=$ wind speed which is meteorology characteriztic [km/hour],

$Z_{0}=$ length of friction at upstream bridge [mm],

$P_{B}=$ basic wind pressure

Table 1. $V_{0}$ and $Z_{0}$ parameters for upstream condition (BSN 2016)

\begin{tabular}{|c|c|c|c|}
\hline Parameter & Open field & Sub Urban & City \\
\hline$V_{0}[\mathrm{~km} / \mathrm{hour}]$ & 13.2 & 17.6 & 19.3 \\
\hline$Z_{0}[\mathrm{~mm}]$ & 70 & 1000 & 2500 \\
\hline
\end{tabular}

Table 2. Basic wind pressure (BSN 2016)

\begin{tabular}{|c|c|c|}
\hline Structural Component & $\begin{array}{c}\text { Compression } \\
\text { Wind [MPa] }\end{array}$ & $\begin{array}{c}\text { Suction } \\
\text { Wind [MPa] }\end{array}$ \\
\hline Truss, column, and arch & 0.0024 & 0,0012 \\
\hline Beam & 0.0024 & N/A \\
\hline Flat surface & 0.0019 & N/A \\
\hline
\end{tabular}

The live load that is carried is $20 \mathrm{kN}$ in the middle of the span. This can be seen in Table 1 in the Surat Edaran of the Minister of Public Works No. 02/SE/M/2010 concerning Implementation of Guidelines for Planning and Implementation of Suspension Bridge Construction for Pedestrians. Based on the Load and Resistance Factor Design (LRFD) for Highway Bridge Superstructures, the deflection requirements for wooden pedestrian bridges are determined using this regulation.

Based on the Design for Earthquake Loads according to the SNI 2833:2008 (BSN 2008), the planned earthquake load is calculated in association with the Peak Ground Accelerations (PGA) on the Indonesia earthquake hazard map. The calculation results and earthquake load curves can be obtained from secondary data (Pusperkim 2011).

\section{Methods}

At the literature review stage, a study of basic theories related to the design of a simple earthquake-resistant wooden bridge for pedestrians was carried out. The sources of this literature study are books, literature, journals, articles and previous research. The data required for modeling after a literature study is wood mechanics data. The data is obtained based on primary and secondary data. Data on compressive strength parallel to fibers and shear strength of wood are obtained from the results of research conducted by Pranata et al. (2017). While the bending data obtained from laboratory test results. The data obtained refers to SNI, namely the timber flexural strength (SNI 03: 3959: 1995) and the timber shear strength (SNI 03: 3400: 1994).

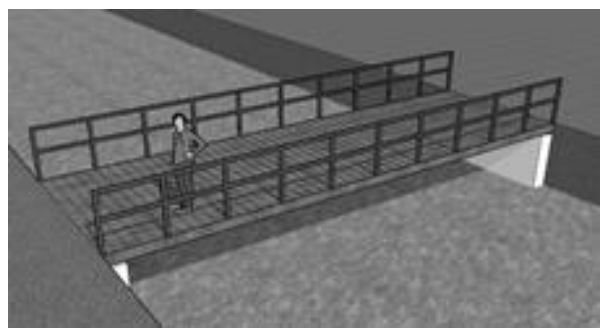

Figure 1. Schematic of Pedestrian bridge (Delima 2018).

This bridge is designed with a length of ten meters, a width of three meters, and a railing height of one meter. Bridge modeling using SAP2000 (CSI 2010) software can be done. This software is used because it has complete analysis features. Modeling carried out on SAP2000 
software includes defining the wood mechanics data material, dimensions of girders and floor plates, and loading.

The aims of structural analysis are to determine the behavior of the bridge and the internal forces acting due to the working loads. Structural analysis can be done if the bridge modeling in SAP2000 software has been completed and is continued with run. Then the inner force will be obtained on the girder which is then used to design the dimensions of the girder and joints, as well as the deflection value to determine whether it meets the requirements or not. The design results are obtained when modeling, structural analysis, and connection design have been completed. The results of this design include the design of the bridge structure, girder dimensions, and the bridge connection system..

\section{Result and Discussion}

After testing the flexural strength test in the laboratory, the flexural strength value is $36.175 \mathrm{MPa}$ with an elastic modulus (E) value of $10.626 \mathrm{MPa}$ obtained from Pranata et al. (2017) research.

Based on the results of the structural analysis (Delima 2018), the maximum deflection value was $19.888 \mathrm{~mm}$, which means that it meets the requirements because it is greater than the permit deflection of $23.529 \mathrm{~mm}$. The force in the greatest moment of the longitudinal girder occurs at frame 2, which is $129,806,282.7 \mathrm{Nmm}$. Meanwhile, the maximum shear force occurs at frame 3 which is $57,629.93$ $\mathrm{N}$. The force in the greatest moment of transverse girder occurs at frame 20, which is $23,721,459.45 \mathrm{Nmm}$. Meanwhile, the maximum shear force occurs at frame 22 , which is $34,751.53 \mathrm{~N}$. The diagram of the force in shear and moment can be seen respectively in Figure 2 and Figure 3.

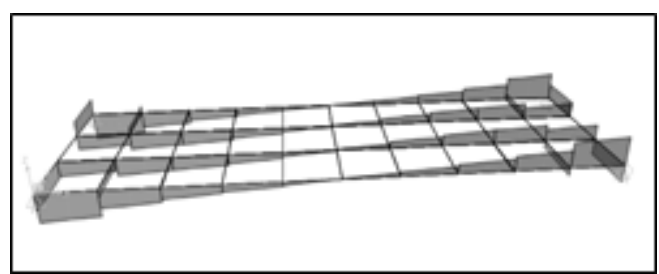

Figure 2. Shear load diagram (Delima 2018).

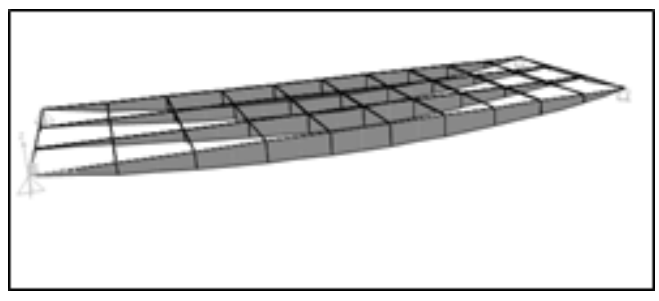

Figure 3. Flexural moment diagram (Delima 2018).
Based on the results of the SAP2000 analysis, the girder dimensions were checked based on the maximum moment and shear values. The size of LVL wood that can be ordered is a multiple of $90 \mathrm{~mm}$. Therefore, dimensions of $360 \times 630 \mathrm{~mm}$ for longitudinal girders and $180 \times 270 \mathrm{~mm}$ for transverse girders are used. The top view of the plate less bridge can be seen in Figure 4, while the three-dimensional bridge can be seen in Figure 5.

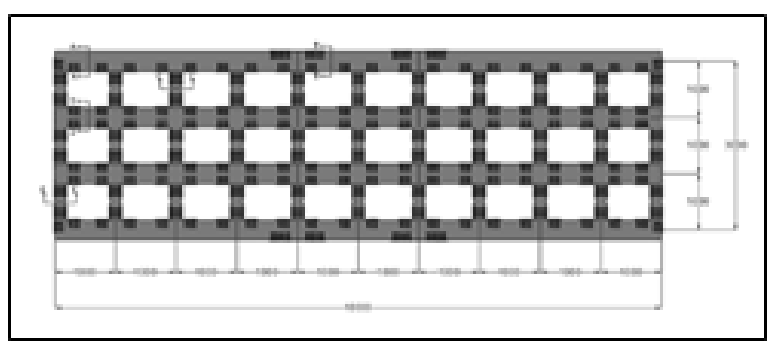

Figure 4. Top view of bridge (Delima 2018).

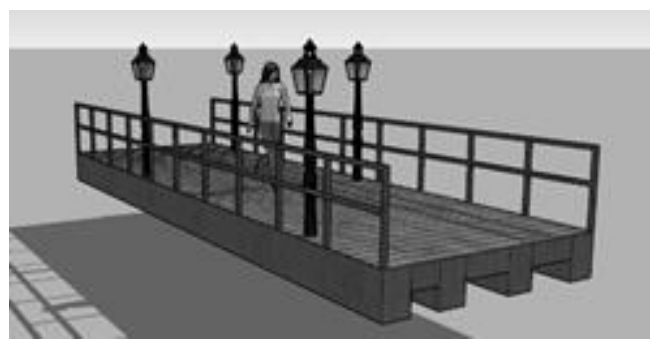

Figure 5. Schematic 3D of bridge (Delima 2018).

By using the dimensions of the girder, based on the results of analysis, the deflection value obtained was 19.888 $\mathrm{mm}$. This value meets the requirements because it is less than the deflection value of the permit, namely $1 / 425$ span or $23.529 \mathrm{~mm}$.

Based on the value of the force in moment and shear of each point connected, the required number of bolts or lock screws is obtained. The joints are designed with a lock bolt or screw and a steel plate with a thickness of $10 \mathrm{~mm}$. The bolts and lock screws used are $16 \mathrm{~mm}$ in diameter with a length of $15 \mathrm{~cm}$ for lock screws and $20 \mathrm{~cm}$ for bolts. For the connection between longitudinal girders, it takes 40 lock screws with a total of 5 bolts per row of 8 rows. As for the connection of the longitudinal girder and the transverse girder, 3 bolts are needed with a total of 3 bolts per row of 1 row. Details of the three-dimensional visible joints between the longitudinal girder and the longitudinal girder and the transverse girder can be seen in Figure 6 and Figure 7, respectively. 


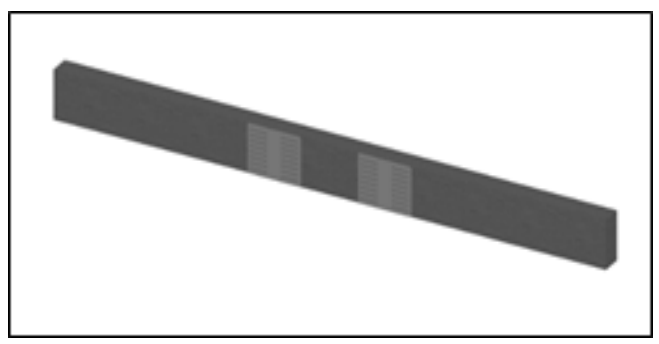

Figure 6. Connection of longitudinal girders (Delima 2018).

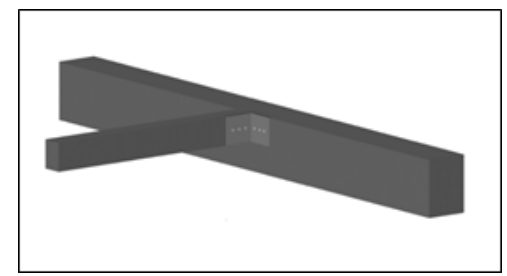

Figure 7. Connection of longitudinal girder and transverse beam (Delima 2018).

The design of girder dimensions and joint systems is planned with the following considerations:

1. The cross section of the $T$ beam cannot be used because it cannot withstand the acting shear forces, so a square beam section is used.

2. The dimensions of the girder used are in accordance with the provisions, namely in multiples of $90 \mathrm{~mm}$.

3. The connection between the longitudinal girders is connected between 3 girders, namely $4 \mathrm{~m}, 2 \mathrm{~m}$, and 4 $\mathrm{m}$, because the maximum length of the LVL log that can be used is $4 \mathrm{~m}$.

4. The number of bolts and lock screws in the connection is planned with the largest internal force value, so that the number of bolts and lock screws for each type of connection is the same. This aims to improve efficiency in the field.

A lock screw with a diameter of $8 \mathrm{~mm}$ is used for the railing connection with the floor plate of the bridge, because if a larger diameter of the lock screw is used, the tip spacing and spacing requirements in the connection configuration will not be fulfilled, which will cause failure in the connection.

\section{Conclusions}

After planning a simple earthquake-resistant wooden bridge for pedestrians for a span of 10 meters and a width of 3 meters, the dimensions of the girder used are $360 \times 630$ $\mathrm{mm}$ for the longitudinal girder and $180 \times 270 \mathrm{~mm}$ for the transverse girder. By using these dimensions, the deflection that occurs has met the actual deflection requirements, which is $19.888 \mathrm{~mm}$ smaller than the $23.529 \mathrm{~mm}$ permit deflection. The connection is designed with a bolt and screw connection tool. Based on the planning results, the number of bolts and lock screws obtained is strong enough to withstand the loads acting on the bridge structure. The diameter of the bolts and lock screws used is $16 \mathrm{~mm}$. The connection between the longitudinal girder is designed with 40 locks screws, namely eight five-row locks screws, and the connection between the longitudinal girder and the transverse girder is designed with three bolts or lock screws in one row.

\section{Acknowledgement}

The authors would like to thank Samko Timber and PT. Sumber Graha Sejahtera, for the support of the LVL wood material which was used as the raw material for the research material.

\section{References}

Awaludin, A.; P. Astuti. 2016. Study on Utilization of LVL Sengon (Paraserianthes falcataria) for Three-Hinged Gable Frame Structures, International Journal of Engineering and Technology Innovation 6 (3).

Awaludin, A.; S. Shahidan; A. Basuki; S.S.M. Zuki; F.M. Nazri. 2018. Laminated Veneer Lumber (LVL) Sengon: An Innovative Sustainable Building Material In Indonesia. International Journal of Integrated Engineering 10(1):, 17-22.

Badan Standardisasi Nasional (BSN). 2008. Perancangan jembatan terhadap beban gempa (SNI 2833:2008). Jakarta: Badan Standardisasi Nasional. (In Indonesian).

Badan Standardisasi Nasional (BSN). 2013. Spesifikasi Desain untuk Konstruksi Kayu (SNI 7973:2013). Jakarta: Badan Standardisasi Nasional. (In Indonesian).

Badan Standardisasi Nasional (BSN). 2016. Pembebanan Untuk Jembatan (SNI 1725:2016). Jakarta: Badan Standardisasi Nasional. (In Indonesian).

Badan Standardisasi Nasional (BSN). 1995. SNI 03: 3959: 1995 Metode pengujian kuat lentur kayu di laboratorium (in Indonesian).

Badan Standardisasi Nasional (BSN). 1994. SNI 03: 3400: 1994 Metode pengujian kuat geser kayu (in Indonesian).

Computer and Structures, Inc. (CSI). 2010. SAP2000 user guide, Computer and Structures, Inc., 1995 University Ave. Berkeley, CA 94704, USA.

Delima. 2018. Perencanaan Jembatan Kayu Tipe Balok Sederhana Tahan Gempa Untuk Pejalan Kaki, Tugas Akhir (tidak dipublikasikan). Program Studi Teknik Sipil, Fakultas Teknik Sipil Dan Perencanaan, Institut Teknologi Nasional Bandung. (In Indonesian).

Government Regulation of the Republic of Indonesia Number 34 Year 2006 (Peraturan Pemerintah Republik Indonesia Nomor 34 Tahun 2006) Tentang Jalan. (In Indonesian).

Herbudiman, B.; Y.A. Pranat; L. Pangest. 2017, Design of Pedestrian Truss Bridge with Sengon-Rubber Laminated Veneer Lumber, The International 
Conference on Eco Engineering Development 2017, IOP Publishing Conf. Series: Earth and Environmental Science Volume 109, doi: 10.1088/17551315/109/1/012029.

Ministry of Public Works. 2010. Implementation of Guidelines for Planning and Implementation of Suspension Bridge Construction for Pedestrians, "Surat Edaran" No. 02/SE/M/2010 (in Indonesian).

Pranata, Y.A.; A. Kevin. 2016, Struktur Jembatan Rangka Batang Kayu Kelapa, Seminar Nasional Pengabdian kepada Masyarakat, ISSN 2541-3805, Yogyakarta, Indonesia. (In Indonesian).

Pranata, Y.A.; B. Herbudiman; N. Valiantine; L. Pangestu; F. Kawa. 2017. Experimental Report of Mechanical Properties of Sengon-Rubber LVL. Bandung: Universitas Kristen Maranatha Bandung (In Indonesian).

Pusperkim. 2011. Desain Spektra Indonesia URL website: http://puskim.pu.go.id/Aplikasi/desain_spektra_indone sia_2011, Pusat Penelitian dan Pengembangan Pemukiman (In Indonesian).

Pusat Penelitian dan Pengembangan Pemukiman. 2014. Retrieved from Teknologi Rumah Tahan Gempa dengan Struktur Kayu Laminasi (LVL): http://puskim.pu.go.id/teknologi-rumah-tahan-gempadengan-struktur-kayu-laminasi-Ivl (In Indonesian).

Bernardinus Herbudiman and Delima

Department of Civil Engineering, Faculty of Civil

Engineering and Planning, Institut Teknologi Nasional,

JI. PHH. Mustofa.23, Bandung 40124, West Java, Indonesia

Tel : +62-8156145665

E-mail : herbudimanb@yahoo.com, and delimanima@yahoo.com

\section{Yosafat Aji Pranata}

Department of Civil Engineering, Faculty of Engineering, Universitas Kristen Maranatha,

JI. Suria Sumantri 65, Bandung 40164, West Java, Indonesia

Tel : + 62-816623703

E-mail : yosafat.ap@gmail.com or yosafat.ap@eng.maranatha.edu 